\title{
Energy from Waste
}

Rupankar Saha ${ }^{1 *}$, and Binay Kumar Singh ${ }^{1}$

${ }^{l}$ Maharashtra Academy of Naval Education \& Training, Pune-412201, India

Abstract. The objective of this paper is to discuss the various technology and methods for producing energy from waste \& its advantages. These technologies are incineration, gasification, plasma arc gasification, pyrolysis, anaerobic digestion. These technologies reduce volume of waste, environmental influence threat to public health and the dependency of the fossil fuel for generating power. The efficiency of this technology is up to $20-40 \%$. As per rough idea, a typical 100000 tonnes per annum waste to energy plant will produce around 7MW of electricity, which is sufficient to power approximately 10,000 homes and cost of the energy is around $0.03 \$-0.05 \$$ per Kilo-watt Hours depend upon the technologies.

1. Introduction: Now-a-days all developing countries are facing challenges regarding collection of waste, transport and deposing of waste, while advanced country are using innovative technology to produce energy from different by-product of waste. The advancement in waste to energy technology provides economical and optical solution for energy and support the energy crisis. The main reason behind for massive waste generation are population boom, high standard of living, better economic growth and increase in global trades [1]. For example in 2018, 62 million metric tons of waste was produced in India and it is prospect that it will become $165 \mathrm{MT}$ by 2031 \& by year 2050 , it will become 436 million tons. The land required to dump 62 million MTs of untreated waste is nearly 1240 hectors per year \& it will expected that the requirement may be expand to 66000 hectors of land required for dumping the waste and also required man power for treating waste with proper technology [2]. This technology help to reduce the volume of waste and assist in energy production. Waste to energy conservation technique support in minimizing the production of waste and keeps environment clean. The world is facing short supply of energy due to resource constraints. Hence, the idea of producing energy from waste is suitable option.

\section{Waste Hierarchy:}

It is a tool used for protecting the environment by managing the waste in terms of what is best for the environment. The aim behind the waste hierarchy is that it helps to reduce the generation waste, reduce the amount of waste goes for landfill and increase in recovery and re-use of resources. It helps in reduction in green houses gases and pollutants which harm environment.

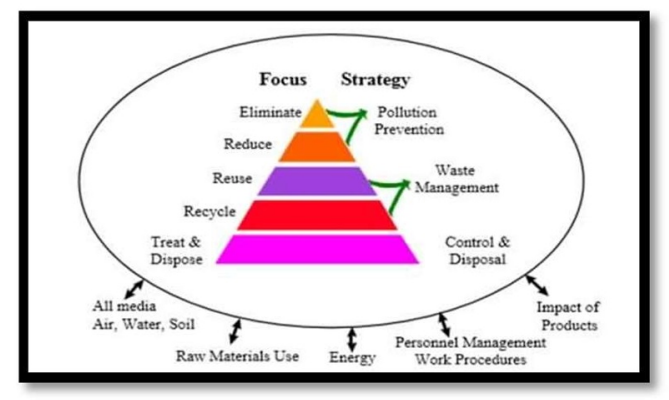

Fig. 1. Waste management hierarchy

\section{5 R Technique for Waste Management:}

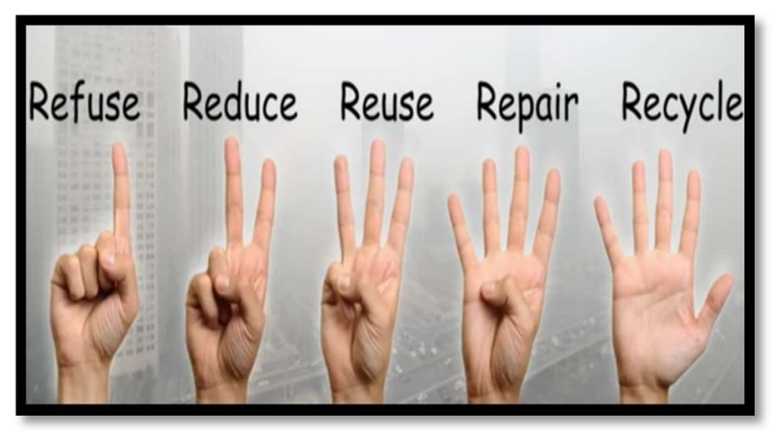

Fig. 2. $5 \mathrm{R}$ Technique for waste management

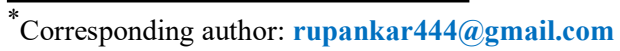




\section{Types of waste:}

\begin{tabular}{|c|c|}
\hline $\begin{array}{l}\text { Waste from } \\
\text { urban }\end{array}$ & $\begin{array}{l}\text { Municipal Solid Waste: Paper, } \\
\text { Glass, Metals, Man-made polymers } \\
\text { such as epoxy, Teflon, polyethylene, } \\
\text { polyester, nylon, cords, coils, } \\
\text { Gadgets, Hides and leather discard } \\
\text { pharmaceuticals wastes ,kitchen waste } \\
\text { Sewage: 1) Bulk excretory matters } \\
\text { (Feces and urine), } \\
\text { 2.) Wastes from the body } \\
\text { (necrosis, spit, tears } \\
\text { 3.) Baths, } \\
\text { 4).Laundry wastes } \\
\text { (Detergent and soap precipitates). }\end{array}$ \\
\hline $\begin{array}{l}\text { Waste from } \\
\text { industry }\end{array}$ & $\begin{array}{l}\text { Solid: 1) Paper and pulp waste } \\
\text { 2) Bagasse (sugarcane, } \\
\text { bamboo, etc.), } \\
\text { 3) Press mud, } \\
\text { 4) Brine mud, } \\
\text { 5) Metallurgical slags, } \\
\text { 6) Gypsum polyesters, etc. } \\
\text { Liquid: 1) Non-soluble of miscible } \\
\text { oil, Paint with emulsion, waste from } \\
\text { oil, } \\
\text { 2) Tarry waste and } \\
\text { Residues/High density metals } \\
\text { 3) Industrial effluents (textile } \\
\text { dyes) } \\
\text { 4) A mixture of liquid with } \\
\text { manure, a mixture of a liquid with } \\
\text { cement } \\
\text { 5).By-product after } \\
\text { cheese/casein manufacture from milk }\end{array}$ \\
\hline $\begin{array}{l}\text { Waste from } \\
\text { biomass }\end{array}$ & $\begin{array}{l}\text { 1) Crop debris (stalks, straws, cobs, } \\
\text { husks, oil cakes, shells, pods, etc.), } \\
\text { 2) Diary forms from where we get } \\
\text { milk } \\
\text { 3) Abattoir wastes (Flesh, Bones, } \\
\text { Organs, and Blood etc.) } \\
\text { 4) Bulk forest wastes (wood, stubbles } \\
\text { and Humus, } \\
5 \text { ) Wastes from forests wood wastes, } \\
\text { leaves, grains, spores in trees }\end{array}$ \\
\hline $\begin{array}{l}\text { Waste from } \\
\text { biomedical }\end{array}$ & $\begin{array}{l}\text { 1) Anatomical wastes and } \\
\text { pathological waste (muscles, glands, } \\
\text { body portion) } \\
\text { 2) Veterinary wastes from animals } \\
\text { 3) Laboratory reagents, } \\
\text { 4) Discarded medicines and cytotoxic } \\
\text { drugs, } \\
\text { 5) Fluids from the body such as } \\
\text { plasma, urine etc. }\end{array}$ \\
\hline
\end{tabular}

\section{Incineration:}

It is a thermochemical technology. It is the most common and oldest method for producing waste to energy. In this process waste is fed into the combustion chamber for burning at a temperature of $900^{\circ} \mathrm{c}-950^{\circ} \mathrm{c}$ with the presence of oxygen $\&$ release heat energy. This heat is utilize to generate steam, which is used to drive the turbine $\&$ produce electricity.

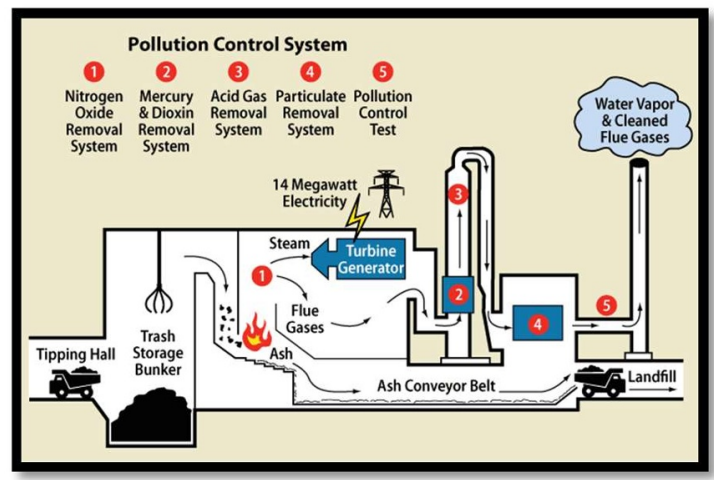

Fig. 3. Schematic diagram of the incineration process By-products of this process are ash and air pollution control residue.in this process, waste reduction potential is around $80 \%$ and efficiency is up to $18-28 \%$ [3].Depending upon the types of furnace, there are 3 types-

\section{$>$ Moving Grate \\ $>$ Fluidised Bed \\ $>$ Rotary Kiln}

5.1. Moving Grate: This is the oldest \& widely used waste to energy technology process. In this process, the waste is fed into a grate by the help of reciprocating, rocking, travelling or rolling movement to convey the waste through combustion chamber. The power efficiency in this process is up to $30 \%$ and combined heat \& power more than $70 \%$ [4]. Types of waste burn in this systems are Municipal solid waste (MSW), Commercial and Industrial (C\&I) waste, Refuse Derived Fuels (RDF), Woods, Hazardous Waste, Clinical waste. There are over 900 plants is present across the world. The indicative cost of this technology $\$ 450-\$ 700$ per tonnent. Treatment capacity of this technology is up to $120 \mathrm{MW}$ [5].

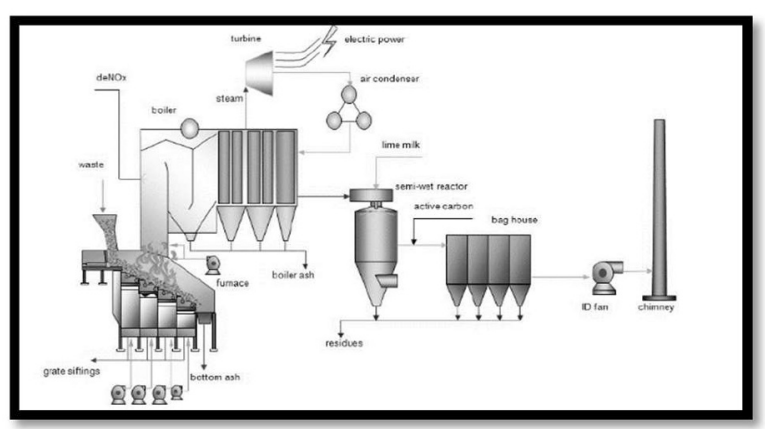

Fig.4. Moving grate technique of incineration process 
5.2. Fluidised bed: Fluidised bed having a vertical combustion chamber. The process is mainly used for coal, raw sewage, sludge and bio-mass. A hot bed is present in the bottom part of combustion chamber. Waste is burned in the hot bed. The material of the bed consisting of sand, ash or other inert material.

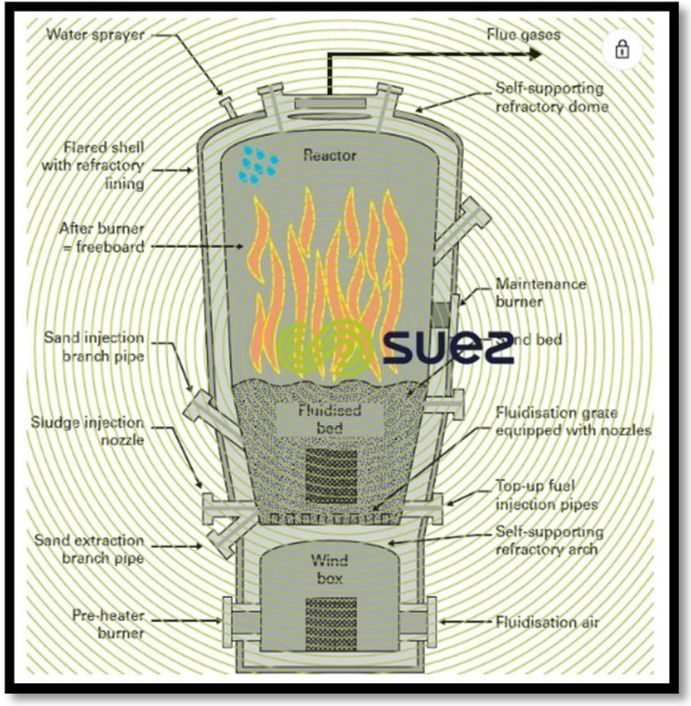

Fig. 5. Fluidised bed technique of incineration

The waste is fed into hot bed from the top or side. Holes are provided for supplying the pre-heated air into the combustion chamber. Power efficiency for this technology is up to $25 \%$ and combined heat and power can reach in this process greater than $70 \%$. Treatment capacity of this technology is up to $90 \mathrm{MW}$. This technology is intensively used in Japan.

If the waste is heterogeneous for this technology requires a preparatory process so it conforms to size specification. For this technology the acceptable limit of the waste particle size less than $200 \mathrm{~mm}$.

This technology is categorized on the basis of gas speed and nozzle design gas speeds and design of the nozzle plate:

$>$ Stationary / Bubbling) fluidized bed

$>$ Rotating fluidized bed

$>$ Circulating fluidized bed

i. Stationary / Bubbling fluidized bed: This technology can be used for generating energy by treating sewage and industrial sludge.

ii. Rotating fluidized bed: This type of fluidized bed is revolved in the combustion chamber, so it's achieve longer residence time in the incineration chamber. This are used for mixed municipal waste.

iii. Circulating fluidized bed: This circulating fluidized bed is used for calcination of dried sewage sludge having high heating value.
* Case study (3grate incinerator lines \& fluidized bed incinerator): Indaver Doel [6].

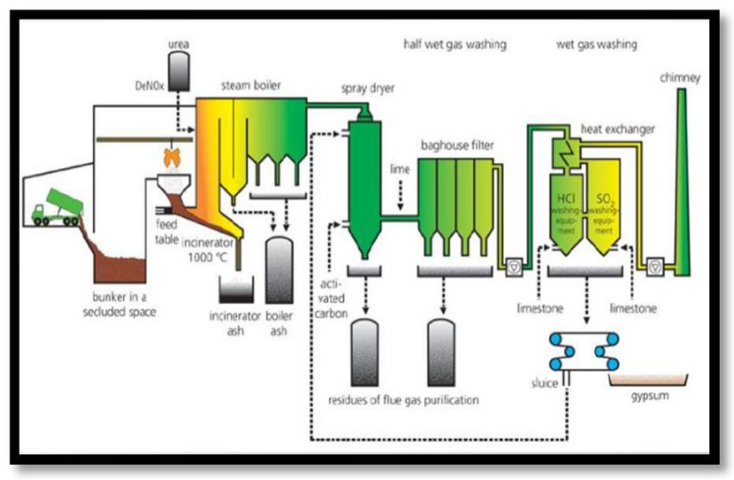

Fig. 6. Grate process of incineration

Types of waste: Non-recyclable MSW and Commercial waste@400000tpa for 3 grate incineration lines.

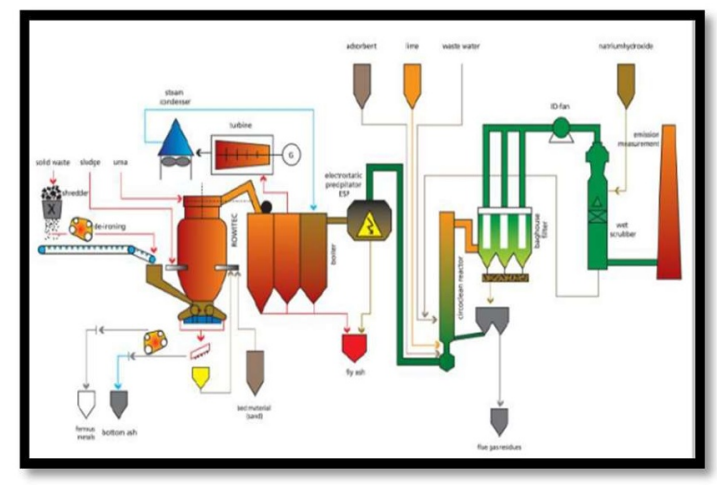

Fig. 7. Fluidized bed incineration

Types of waste: Non-recyclable MSW and commercial waste@600000tpa for Fluidized bed incineration.

Result: It produces electricity to 170000 household \& it supply 30 tph steam to a chemical producing company "Ineos".

5.3. Rotary kiln: It consist of a cylindrical vessel which is inclined at the horizontal axis. This vessel is usually lying on the roller, so the kilns spin or oscillated around its axis normally reciprocating motion.

The waste is introduce to the kiln at higher end and conveyed through the kiln by the gravity as it rotates \& resulting ash discharge through at the lower end.

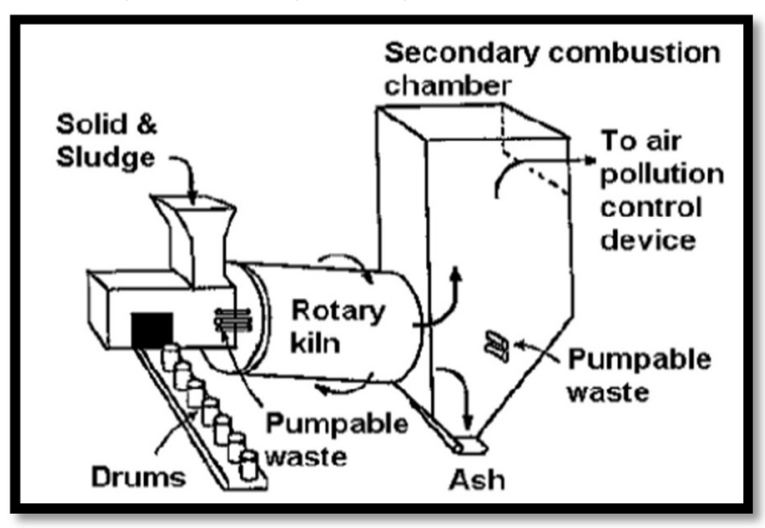

Fig. 8. Rotary kiln process of incineration 
The operating temperature of this kiln from $500^{\circ} \mathrm{c}$ to $1450^{\circ} \mathrm{c}$. If the hazardous waste is used for this technology, the temperature range $900^{\circ}-1200^{\circ} \mathrm{c}$ [7] hazardous waste and also used for clinical waste, sewage sludge and waste water sludge. Power efficiency of this technology is up to $25 \%$ and combined power and heat recovery more than $70 \%[8]$

\section{Pyrolysis:}

In this technology organic material (i.e. cellulose, hemicellulose and lignin) is exposed at high temperatures with in inert atmosphere (absence of oxygen). In this treatment, material is exposed to elevated temperature and passes through chemical and physical separation into different molecules. It is mostly used for treating organic material and plastic. Depending upon the configuration of pyrolysis equipment there are 3 types such as fluidised bed, Moving bed and Rotating cone. Power efficiency of this technology is up to $23 \%$ $\&$ regenerative efficiency i.e. power and heat up to $81 \%$ through the steam turbine [9].

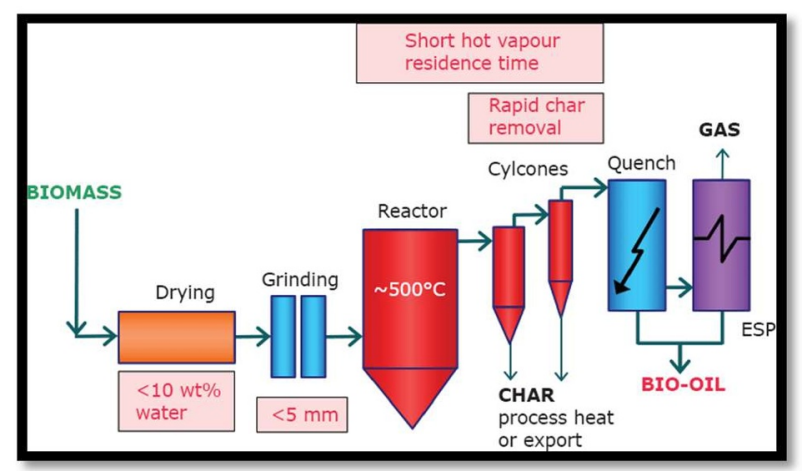

Fig. 9. Schematic diagram of pyrolysis technique.

Types of pyrolysis:-

1) Slow pyrolysis:- In this process the heating temperature is in between $400^{\circ} \mathrm{c}-500^{\circ} \mathrm{c}$ and the residence time is $5-30 \mathrm{~min}$.

2) Fast pyrolysis:- In this process the heating temperature is in between $400^{\circ} \mathrm{c}-650^{\circ} \mathrm{c}$ and the residence time is $0.5-2 \mathrm{~s}$. The major products are biooil, gases and char.

3) Flash pyrolysis:- In Flash pyrolysis, heating temperature is in between $700^{\circ} \mathrm{c}-1000^{\circ} \mathrm{c}$ i.e. very high and the residence time is $<0.5 \mathrm{sec}$.
* Categorization of pyrolysis process on the basis of heating rate, major products and residence time [10].

\begin{tabular}{|l|l|l|l|l|}
\hline Method & $\begin{array}{l}\text { Temperature } \\
\left({ }^{\circ} \mathrm{c}\right)\end{array}$ & $\begin{array}{l}\text { Residence } \\
\text { time }\end{array}$ & $\begin{array}{l}\text { Heating } \\
\text { rate } \\
\left({ }^{\circ} \mathrm{c} / \mathrm{s}\right)\end{array}$ & $\begin{array}{l}\text { Major } \\
\text { products }\end{array}$ \\
\hline $\begin{array}{l}\text { Slow } \\
\text { Pyrolysis }\end{array}$ & $400^{\circ} \mathrm{c}-500^{\circ} \mathrm{c}$ & $5-30 \mathrm{~min}$ & 10 & $\begin{array}{l}\text { Gases } \\
\text { Char } \\
\text { Bio-oil } \\
\text { tar }\end{array}$ \\
\hline $\begin{array}{l}\text { Fast } \\
\text { pyrolysis }\end{array}$ & $400^{\circ} \mathrm{c}-650^{\circ} \mathrm{c}$ & $0.5-2 \mathrm{~s}$ & 100 & $\begin{array}{l}\text { Bio-oil } \\
\text { thinner }) \\
\text { Gases } \\
\text { Char }\end{array}$ \\
\hline $\begin{array}{l}\text { flash } \\
\text { pyrolysis }\end{array}$ & $700^{\circ} \mathrm{c}-1000^{\circ} \mathrm{c}$ & $<0.5 \mathrm{~s}$ & $>500$ & $\begin{array}{l}\text { Gases } \\
\text { Bio-oil }\end{array}$ \\
\hline
\end{tabular}

\section{* Output product from Pyrolysis and its use :}

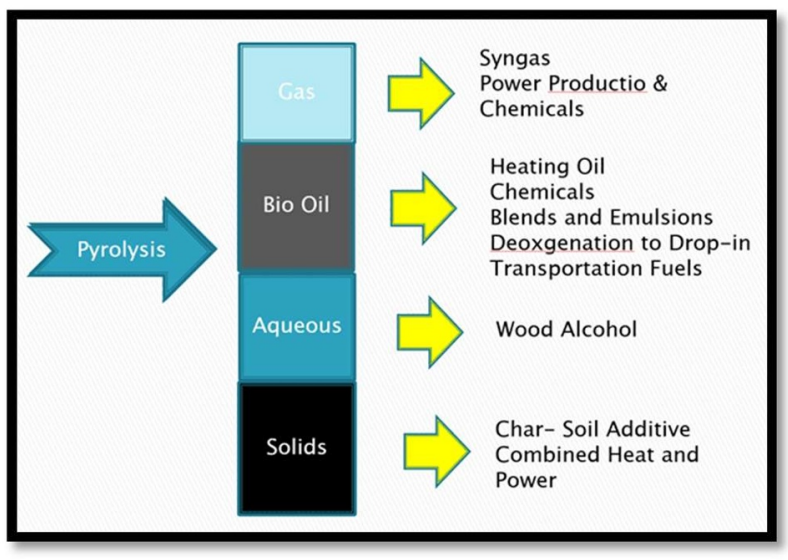

Fig. 10. Products of pyrolysis

\section{Gasification:}

It is a partial oxidation process where the $80 \%$ of the chemical energy in the waste specially carbon \& hydrogen being converted into syngas or synthesis gas. This gas can be used to provide energy to steam boiler and gas engines.

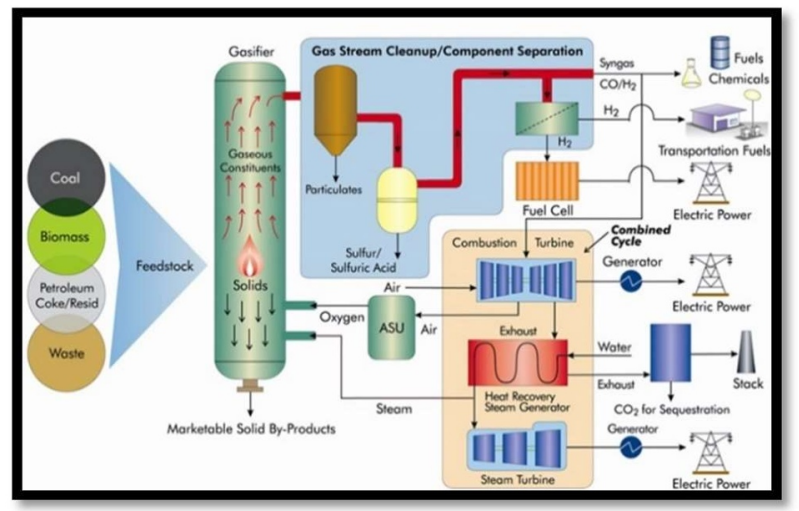

Fig. 11. Schematic diagram of Gasification process

The temperature range of this process $500^{\circ} \mathrm{c}-1800^{\circ} \mathrm{c}$ and power efficiency in this process is up to $23 \%$ and regenerative efficiency i.e. power and heat is up to $81 \%$ 
using steam turbine [11]. This process helps to recover the energy present in biomass and municipal solid waste by converting those material into valuable products and eliminating the need for incinerator landfilling. Products obtain from syngas includes chemical (45\%), liquid fuel (28\%), gaseous fuels (8\%) and electric power (19\%). This process helps in reducing the volume of solid waste up to $85 \%$ to $92 \%$ and reduce the amount of SOx, NOx and dioxins.

\section{Plasma Gasification:}

This technology uses an electric arc to produce high temperature within the reactor to convert solid waste or hazardous waste (asbestos and radioactive) to syn gas and melt arising from inorganic species of feedstock.

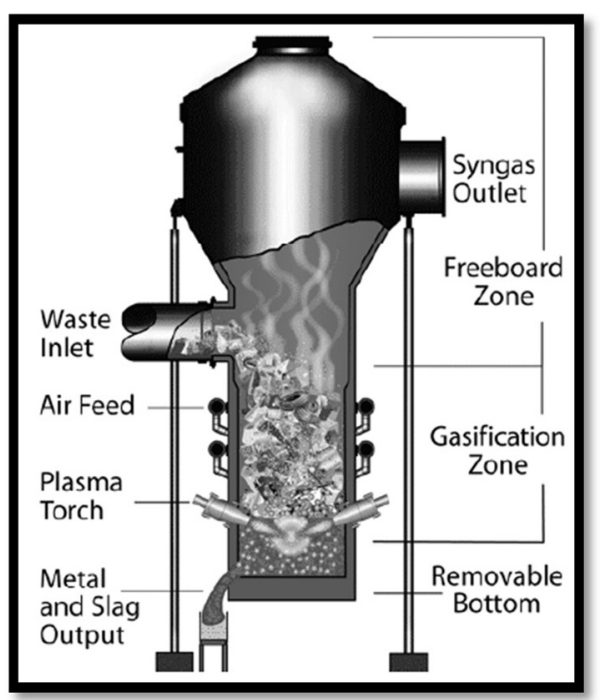

Fig. 12. Plasma arc Gasification system

This technology reduce the tar content by 1000 times less than of conventional Gasification [12].Temperature range of this process as high as $7000^{\circ} \mathrm{c}$. Syngas is produced in this process more cleaner than conventional combustion. Power efficiency of this process is up to $23 \%$ [13]. Plasma is an electrically conductive gas (nitrogen \& argon) which are heated by an electrical current to very high temperature. Requirement of Oxygen is very less in this process compared to conventional Gasification. Example of this type of plant is Alter NRG (Westinghouse). There are 3 mains types of plasma gasification available such as-

- Direct exposure to plasma torch (only for high level hazardous waste).

- Plasma assisted gasification

- Plasma for syngas polishing.

\section{Anaerobic Digestion:}

In this process biological treatment of organic materials is done with the help of micro-organism which break down organic material into smaller particle in oxygen poor environment with the help of different types of bacteria \& release combustible bio-gas methane \& carbon di-oxide which are used to produce heat electricity \& bio-fuel.

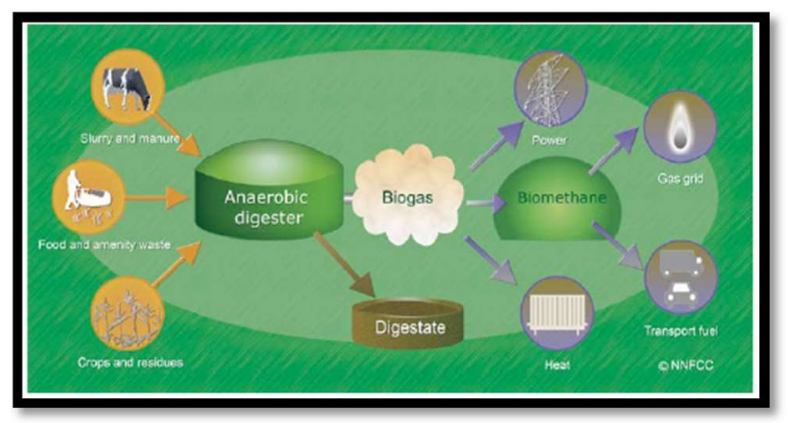

Fig. 13. Anaerobic Digestion Process

For this technology we can use various feedstock such as Bio-solids, Food waste, green waste, crop residue, sewage sludge \& other higher moisture content waste. There are main four steps of Anaerobic Digestion process such as Hydrolysis, Acidogenesis, Acetogenesis, Methanogenesis.

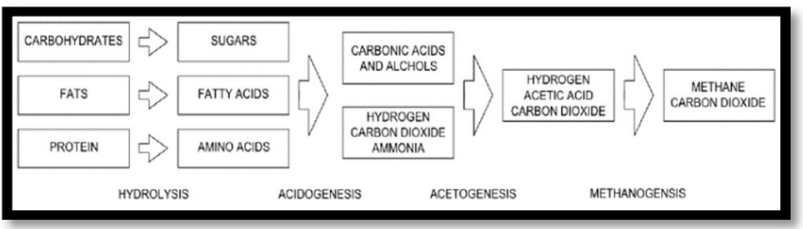

Fig. 14. Steps to production of methane from various organic compound.

- Hydrolysis: In this process large protein molecules, complex of fats, carbohydrates are brake through with the help of hydrolysis and produce amino acids, long chain fatty acids \& sugar.

- Acidogenesis: In this stage sugar, fatty acid, amino acid converted into three, four $\&$ five carbon volatile fatty acid such as lactic, butyric acid and valeric acid.

- Acetogenesis: Here, volatile fatty acids are converted into acetic acid, carbon dioxide and hydrogen with the help of Acetogenesis bacteria.

- Methanogenesis: In this stage, methane gas is produce with the help of methane-forming bacteria which digest acetate, carbon dioxide and hydrogen.

The end product of this process is bio-gas, which consist of methane $\left(\mathrm{CH}_{4}\right)(50-70 \%), \mathrm{Co}_{2}(30-45 \%), \& \mathrm{H}_{2} \mathrm{~S}(200-$ 4000ppm) [14].

* Example for this type of plant is Tilburg plant which uses Valogra process. It has an annual waste capacity 52,000 tons of garden and vegetable waste per year. This plant having two digester, each of $3300 \mathrm{~m}^{3}$ capacity \& produces 2.8 million $\mathrm{m}^{3}$ of methane per year. Each ton of waste produce approximately $106 \mathrm{~m}^{3}$ bio-gas. The retention duration time is 20 days at mesophilic temperature of $38^{\circ} \mathrm{c}[15]$. 


\section{Conclusion:}

India is an energy deficient country with the dense populations in the urban areas. The energy from every source is an important and essential necessitate. With increase in population, the production of waste is also increased and thus we can use this waste for producing energy. Life cycle assessment studies suggest that waste to energy production is better way to tackle the problem arise from waste management. Power produced from the WTE production activity can reduce the load on natural resources. Most of the electricity in India produce from fossil fuels, so fossil fuel are reducing day by day whereas waste is rising progressively. Electricity production from waste helps in reducing the load on fossil fuels and also helps in reduction on $\mathrm{CO}_{2}$ emission by $20-25$ million $\mathrm{kg} /$ year. It also helps in reduction of $\mathrm{SO}_{2}, \mathrm{NO}_{\mathrm{X}}$ etc. WTE technology counter the problem regarding waste management and energy generation for example waste from Kanpur city produced 33MW electricity which satisfy $5 \%$ electricity demand of Kanpur city. So, it reduces the problem regarding waste management by decrementing volume of waste by $90 \%$.

\section{REFERENCE:}

1. M. Rehan, J. Gardy, A. Demirbas, U. Rashid, W. M. Budzianowski, D. Pant, and A. S. Nizami, Bioresour. Technol. 250:17-25 (2018)

2. J. Charles Rajesh Kumar, B. Mary Arunsi, R. Jenova, and M. A. Majid, Int. J. Renew. Energy Res. Vol.9, No.1, (March 2019).

3. EU-Indonesia Trade Cooperation Facility, 82, (2015).

4. Ricardo-AEA/R/ED58135/Issue Number 5 - Final Report, 11, (02/07/2013).

5. S. Boshoff, Overview of thermal technologies for waste to energy application, 15, (7 April, 2016).

6. S. Boshoff, Overview of thermal technologies for waste to energy application, 19-20, (7 April, 2016).

7. A. Bosmans and L. Helsen, in Third Int. Symp. Energy from Biomass Waste (November, 2010)

8. Ricardo-AEA/R/ED58135/Issue Number 5 - Final Report, 14, (02/07/2013).

9. Ricardo-AEA/R/ED58135/Issue Number 5 - Final Report, 26, (02/07/2013).

10. S. I. Ahmed, A. Al Fatta, M. J. Hossain, and S. Tanvir, Int. Conf. Energy Environ. 3 (2018)

11. Ricardo-AEA/R/ED58135/Issue Number 5 - Final Report, 26, (02/07/2013).

12. M. Saghir, M. Rehan, and A.-S. Nizami, in Gasif. Low-Grade Feed, 106, (1 $1^{\text {th }}$ July 2018).

13. Ricardo-AEA/R/ED58135/Issue Number 5 - Final Report, 24, (02/07/2013).

14. S. Verma, Anaerobic digestion of biodegradable organics in municipal solid wastes. Fu Foundation School of Engineering and Applied Science, Columbia University, (2002).

15. M. McCrea, T.K. Tan, H. H. Ting, X. Zuo, A Cost Benefit Analysis of Different Waste to Energy Technologies for the Management of Municipal Solid Waste in Singapore, 7. 